\title{
Use-Based Welfare: Property Experiments in Chicago, 1895-1935
}

\author{
Nate Ela \\ Forthcoming in Social Science History
}

\begin{abstract}
Use-based welfare achieves redistribution by reallocating rights to use and benefit from idle resources, rather than via tax and transfer. How and why has this form of welfare provision emerged as an urban institution, and what affects whether it endures? This article compares projects to grant poor and unemployed Chicagoans access to land for gardens and small farms between 1895 and 1935, explaining how this form of social support came about through experiments with rules, norms, and forms of property. While social policy is typically understood as emerging through the realization of rights to public support, use-based welfare turns instead on efforts to create a legal privilege for the needy to use idle resources. During the Progressive Era and the Great Depression, this form of relief was pitched as both an alternative and a complement to welfare based on tax and transfer. Yet efforts to establish it as a permanent institution repeatedly failed, due to implementation challenges, opposition from people committed to treating land and food as commodities, and the non-emergence of a social movement to defend land access. Recognizing the historical dynamics of use-based welfare offers a new perspective on the contemporary resurgence of urban farming as a strategy for addressing unemployment and poverty.
\end{abstract}




\section{Biographical Note}

Nate Ela has a $\mathrm{PhD}$ in sociology from the University of Wisconsin-Madison and a JD from Harvard. A visiting researcher at the American Bar Foundation, he will lecture at Northwestern University Law School in 2019. His research examines historical and contemporary experiments with law, social policy, and democracy in U.S. cities, as well as the politics of international human rights. Recent works have appeared in Law \& Social Inquiry and the Fordham Urban Law Journal. 


\section{Use-Based Welfare: \\ Property Experiments in Chicago, 1895-1935}

Over the past decade, farms and gardens have been cropping up around Chicago. In Englewood, a South Side neighborhood where work has disappeared and vacant lots are abundant, the city has created an urban agriculture district. Farms offer job training to the unemployed and summer work for "at-risk" youth. They sit on land leased by the parks district, and vacant lots that the city has transferred to an urban agriculture land trust. City plans call for a system of public open spaces for large-scale food production, where entrepreneurial growers in high-poverty neighborhoods can earn "supplemental income" by farming (City of Chicago 2013: 17-18; 2014: 30-32).

What accounts for this move back to the land? Chicago's embrace of farms and gardens might be seen as a response to consumer demand—from residents of so-called "food deserts" (Gallagher 2006), restaurant patrons hungry for hyper-local food, or people willing to pay a premium to live near a community garden (Voicu and Been 2008). This article proposes an alternate explanation. As welfare programs have been cut, and benefits made contingent on work requirements, the turn to urban agriculture also signals the re-emergence of a type of redistributive social policy common before the creation of the modern welfare state. Rather than

Versions of this paper were presented at the American Sociology Association Economic Sociology Section's 2016 pre-conference workshop and at a 2017 ASA session on the welfare state organized by Ann Orloff. I am grateful for comments at those meetings, as well as from participants in the Economic Sociology Workshop at the University of Wisconsin-Madison and the Boston College Environmental Sociology Working Group, and from the anonymous reviewers. Special thanks are due to Meghan Morris and Erik Olin Wright. This research has received support from the Social Science Research Council, the National Science Foundation, and the Lincoln Institute for Land Policy. 
redistributing via tax and transfer, this form of social policy, which I refer to as use-based welfare, does so by reallocating rights to use and benefit from idle resources.

This article explains how and why social reformers have repeatedly experimented with land use as a basis for supporting the needy. I examine and compare how this longstanding form of redistribution figured in welfare provision in Chicago during the Progressive Era and the Great Depression. Who supported it, and who opposed it? How did it relate to other forms of welfare provision? And in contrast to those other forms, why has use-based welfare periodically emerged and then disappeared?

I explore these questions by comparing how social reformers and municipal officialsfrom residents of the Hull House social settlement and wartime garden campaigners to Depression-era relief workers - worked to grant poor and unemployed Chicagoans the ability to grow food on vacant pieces of land. This sheds light on how reformers developed organizational, institutional, and discursive strategies to use idle land to alleviate poverty and unemployment. And it helps account for why use-based welfare has not become a permanent urban institution. Urban farms and gardens have periodically emerged as reformers have brokered rights to use land; the reluctance of these brokers to act as organizers has, in turn, hampered the creation of movements that could defend and entrench use-based welfare.

By identifying connections between land use and social policy, the article offers a new perspective on urban agriculture. Social scientists have generally seen urban growing as part of a movement for just, sustainable, and local food systems (Allen 2008; White 2011). This centers attention on dynamics and contradictions of movement organizing (McClintock 2013; Lyson 2014). This study focuses instead on the property rules that define the conditions of possibility for urban growing, revealing how urban agriculture relates to urban institutions and social policy. 
In the process, it points to possible stumbling blocks for movements to make farms and gardens a permanent feature of urban landscapes.

It is tempting to read the history that emerges as one of a path not taken. A century ago, giving the unemployed poor access to vacant urban land was a common strategy for social support in America's cities. Yet since the rise of the modern welfare state, making idle resources available for use by the poor and unemployed has largely fallen off the social policy agenda. When social reformers, state officials, and sociologists think of welfare provision, it is usually in terms of income supports or social services. When we think of land use, it is not usually in terms of social policy. Recognizing how the two are connected requires effort. Retracing how such connections have played out in the past offers a new perspective on the institutional landscapes of our cities, and suggests parallels between past and present. Use-based welfare may not be just a historical artifact - it may also be a form of redistribution once again on the rise.

\section{Welfare Provision: A Fourth Way}

Studies of social policy have focused on three types of welfare provision. These can be categorized by reference to the means of resource distribution, and the type of right granted to beneficiaries. Redistribution often results from tax-and-transfer policies, but can also be achieved by altering property laws to grant beneficiaries a claim to a resource. Whichever the mode of redistribution, beneficiaries may acquire full ownership rights to a resource, or simply the rights

to use and enjoy it. Conceptualizing welfare provision according to these distinctions yields four ideal types (Table 1).

\section{[Table 1 about here]}


Use-based welfare differs from the forms of social policy with which we are most familiar. It does not redistribute via tax and transfer. Nor does it grant full ownership rights to a resource. Instead, it simply reallocates the rights to use and benefit from a resource. To understand how and why people mobilize to bring about this form of redistribution — and how institutions of use-based welfare emerge, stabilize, and disappear-I ask how the dynamics of this type of welfare provision may parallel, or differ from, more familiar forms of social policy.

Explanations for the emergence and entrenchment of income supports have varied. Some scholars have focused on demands made against the state, whether by social movements (Piven and Cloward 1977), labor movements (Esping-Anderson 1990), or reformers seeking disaster relief (Dauber 2013). Others have argued that, once in place, redistributive programs have a "ratchet effect" as beneficiaries enjoy new benefits and resist cutbacks (Huber and Stephens 2001: 28-29), and create the basis for alternative alliances that defend new institutions of social policy (Weir et al. 1988: 17).

Since the 1990s, welfare supports have increasingly taken the form of services provided by nonprofit organizations (Smith and Lipsky 1995; Salamon 1995). Here, beneficiaries receive the benefit of using services funded by taxes, rather than a claim to a share of tax revenues. This shift toward service-based welfare has been explained as a product of community-based organizations brokering access to resources, while mobilizing beneficiaries as political constituents to lobby the state for increased funding (Marwell 2004; Small 2006).

Meanwhile, policy entrepreneurs have promoted asset-based welfare as a "third way" alternative to income supports and service provision (Sherraden 1991; Ackerman and Alstott 2000). One version of asset-based welfare uses tax revenues to subsidize ownership, rather than 
(or in addition to) income supports. ${ }^{1}$ Another redistributes by reforming property law so as to broaden the ownership of assets. In the global south, this has included land titling for urban squatters (de Soto 2000) and land reforms for the rural poor (Wolford 2007). Proponents cite "asset effects" as evidence that the value of ownership is not only economic (Bynner and Paxton 2001), but also increases self-sufficiency and well-being (Cho 1999; Bynner and Despotidou 2001).

There is also a fourth way: supporting the poor by sharing the use and benefits of idle resources. This practice has a long history, particularly when the resource in question is land. Passages in Leviticus (19:9-10) and Deuteronomy (24:19) instruct farmers not to harvest the corners of their fields, to allow gleaning by the poor (Singer 2001). From the late 1600s through the 1800 s, European social thinkers and reformers proposed ways to restore use rights to the unemployed poor, who had been dispossessed of customary rights to common lands. These ranged from the Diggers' occupation and collective cultivation of common land (Winstanley 1649) and Locke's (1980 [1690]) proposal that surplus private property revert to the commons, to projects to keep England's rural poor off of parish lists by letting them use waste lands (Young 1801), and Marx's (1975 [1842]) defense of customary rights to gather wood from Germany's forests. During a visit to France, Thomas Jefferson (1986 [1785]) reasoned that "Whenever there is in any country, uncultivated lands and unemployed poor, it is clear that the laws of property have been so far extended as to violate natural right." When landless people cannot find work, he argued, "the fundamental right to labour the earth returns to the unemployed." Yet he deemed it too soon in the United States "to say that every man who cannot

\footnotetext{
${ }^{1}$ For example, under the 1996 Welfare Reform Act, U.S. states had the option to fund Individual Development Accounts.
} 
find employment but who can find uncultivated land, shall be at liberty to cultivate it, paying a moderate rent."

In Europe, however, gardens cropped up as a form of social provision. In England, allotment gardens emerged in the 1700s and were written into legislation during the $1800 \mathrm{~s}$ (Burchardt 2002). In France and Germany, the Red Cross and private firms used garden programs to support the poor during the nineteenth century (Nilsen 2014). As we will see, Americans followed suit following the Panic of 1893.

Unlike other forms of welfare provision, which have become entrenched institutional features of the modern state, use-based welfare has come and gone. What accounts for this cycle of emergence and disappearance? How do advocates renegotiate use-rights, at least temporarily, so that the unemployed and poor can use vacant land? And what hampers efforts to establish organizations and institutions of use-based welfare as ongoing features of an urban landscape?

Part of the story, the Chicago case study suggests, involves how use-based welfare has straddled the blurry lines between private and public in how cities have administered welfare supports (Katz 1996: 43-47). Private charity and public relief have long coexisted, along with different conditions for helping the needy. Proponents of private charity (understood as a gift) have long critiqued the supposed potential for public outdoor relief (understood as a right) to promote indolence and dependency (Katz 1996; Fox 2010). In Chicago, use-based welfare projects began as privately-coordinated programs, but soon migrated to include public land and public coordination. In the process, they ran counter to general trends. Cities like Chicago, with a large proportion of immigrants from Europe, tended to support the poor through public relief (Fox 2010). Garden projects, however, targeted European immigrants with a form of private charity hoped to prevent dependence on public relief. As garden projects expanded from private and corporate programs to become a form of publicly-coordinated projects, the built-in work 
requirement also became part of public welfare supports. As we will see, the expectation that growers would work in return for receiving land led was met with ambivalence among some gardeners, even as public projects met opposition from landowners and commercial growers.

Explaining the dynamics of use-based welfare also requires appreciating its

distinctiveness. Scholars often understand social policy as a set of rights created in response to social movement pressure (O’Connor et al. 1999; Piven and Cloward 1977). ${ }^{2}$ These rights correspond to duties the state owes to citizens. The study of the emergence and institutionalization of social policy has focused on how mobilization in different political and social contexts has resulted in different bundles of rights across jurisdictions, creating a "ratchet effect" as benefits become taken for granted (Esping-Anderson 1990; Huber and Stephens 2001; Weir et al. 1988).

Use-based welfare involves a different legal relation. Property owners generally have the right to exclude non-owners. Rather than grant beneficiaries a right, use-based welfare creates a privilege to use a resource - which corresponds to an owner's lack of right to exclude nonowners (Hohfeld 1913: 32-33). In practice, experiments with used-based welfare have approximated this ideal type.

If proponents of cash transfers or service provision respond to poverty by devising and justifying schemes to tax and transfer income or wealth, advocates of use-based welfare face a different challenge. Here, the puzzle is how to reallocate the bundle of rights that structure property relations (Commons 1893: 92) so that the needy may use idle resources. This can require solving a matching problem (Mortensen 1988), to pair resources with potential users. In a

\footnotetext{
${ }^{2}$ Meanwhile, the absence of a demand for rights has been used to explain the non-emergence of social policy (Levitsky 2014).
} 
manner akin to social-service providers (Small 2006), providers of use-based welfare broker access to resources. But rather than brokering access to subsidized services, they facilitate exchanges between owners of idle resources and potential users. These deals arguably improve economic efficiency. ${ }^{3}$ But they also pose a puzzle that implicates equity. How might owners be convinced to help the needy by conceding a "basic feature" of private property (Smith 2012: 1709)—-their right to exclude?

The challenge of institutionalizing use-based welfare involves converting temporary legal and moral claims to use idle resources into something more durable. From what we know of other forms of welfare, we might expect to see efforts to mobilize the power of labor or social movements to entrench use-rights. We might also ask if schemes initially devised as temporary have a ratchet effect, creating policy feedbacks by transforming beneficiaries' preferences and political possibilities. Flipping these explanations, in turn, yields hypotheses concerning why use-based welfare might disappear. Reformers may fail to mobilize political pressure in favor of use-rights. Programs conceived as temporary fixes, or developed as private forms of relief, may fail to produce a policy ratchet effect.

To explain the emergence and non-institutionalization of use-based welfare I also draw on insights from urban and legal sociology. Experiments with remaking property relations intervene in an urban political economy defined by treating both land and food as commodities (Logan and Molotch 1987; Cronon 1991). Promoters of land access for urban growing have acted as norm entrepreneurs (Sunstein 1996), claiming that property owners have an obligation

\footnotetext{
${ }^{3}$ Use-based welfare might seem to improve Pareto efficiency, by increasing one person's welfare without subtracting from that of others (Posner 2014: 14). But as we will see, landowners may differ concerning whether ceding use-rights negatively affects their interests.
} 
to help the needy (Alexander 2009), and advocating new property rules. To justify these changes, reformers have appealed to "use effects"-akin to the "asset effects" claimed by promoters of asset-based welfare. These claims highlight how "problems of welfare economics must ultimately dissolve into a study of aesthetics and morals" (Coase 1960: 43). By asserting the value of deals they broker with landowners, promoters of use-based welfare have sought to bring about new urban property institutions (Bartley 2007; Allard and Small 2013) — and reshape what it means to live and labor in the city.

\section{Methods and Data}

To explain how and why use-based welfare has emerged and disappeared as an urban institution, I compare how people brought about such programs in Chicago between the 1890s and 1935. This reveals patterns and differences between how reformers developed organizational and institutional responses to poverty and unemployment. It also helps identify how their strategies drew on lessons taken from problem-solving in earlier periods (Haydu 1998).

Chicago, the site of this case study, is not claimed to be representative of all cities. Chicago's unique history of intense industrial development, racial segregation, and deindustrialization (Cronon 1991; Satter 2009; Walley 2013) has produced a “surprising preponderance of empty spaces, vacant lots and desolate streets" that distinguishes it from other cities (Small 2007: 413). This is a study of an extreme case, which by "activat[ing] more actors and more basic mechanisms in the situation studied" can yield greater insight than a typical case (Flyvberg 2006: 229). The primary comparative approach is diachronic, analyzing how the relationship between land and social policy has changed over time.

I examine how people have experimented with the institutions of property and land use that define the urban landscape. Following the institutional ethnography of Dorothy Smith 
(2005), I map how reformers seek to change the rules and relationships that define land use in particular places. This double mapping — institutional and physical—focuses on sites in the urban landscape that have served as laboratories for tinkering with norms, rules, and forms of property. By taking property as structuring social relations, I ground recent calls for a relational sociology (Emirbayer 1997) in a century-old insight of legal realists - that property law implicates relations between people, rather than simply between people and things (Hohfeld 1913; Hale 1923; Singer 2000).

I draw on documents produced by Chicago's settlement house reformers, progressive-era firms, and city agencies. I also rely on newspaper articles, which raises the possibility of selection or description bias (Earl et al. 2004). Since newspaper articles serve to trace the progression of events, as well as reveal the positions that authors and editors took toward gardening projects, their potential for description bias provides insight into both how social reformers framed their claims, and how an influential segment of Chicago's elite viewed and amplified those claims.

\section{Vacant Lot Gardening, 1895-1920}

Following the Panic of 1893, social reformers and municipal officials sought to ease the suffering of the poor in America's industrializing cities. In Detroit, Mayor Hazen Pingree launched a program to let the unemployed use land offered by private owners; the project turned 430 acres of vacant lots into gardens. Pingree promised this blend of public coordination and private charity would reduce the tax burden, ordering the poor commission to strike from its rolls anyone who did not apply for a garden (Cialdella 2014: 62-63). Word of "Pingree's Potato Patches" spread quickly, and vacant lot cultivation associations sprung up in New York, Philadelphia, and beyond. Reformers hailed how gardens let the unemployed help themselves 
(Hall 1908; Fels 1920; Lawson 2005). As cities and local agencies scrambled to respond to unprecedented economic distress, the programs aligned with a general skepticism of public outdoor relief (Katz 1996: 37-59, 152-53).

In 1895, the Chicago Tribune solicited an article from Pingree, describing Detroit's garden programs (Pingree 1895). The Chicago Bureau of Charities launched a project to let the poor garden in vacant lots (Bureau of Associated Charities 1898: 16-17). Growers formed a club that met at the Hull House social settlement (Pelham 1909: 423). The project withered after a few seasons, but the landless gardeners kept gathering ("The people's friendly club" 1905-1906).

Hull House did not have its own garden, but its residents were curious about the possibilities. In 1901, the famous anarchist geographer Peter Kropotkin visited and spoke on Fields, Factories, and Workshops (1912 [1898]). The book envisioned urban workers rotating between agriculture, industry, and craft workshops ("World improves, says Kropotkin" 1901). Jane Addams praised the book as "remarkable." (Avrich 1980: 27) Settlement leaders and welfare workers from Chicago's manufacturing firms also discussed gardening during private meetings. During one, a visitor from Ohio explained how his factory had assigned garden plots to "idle and disorderly" neighborhood boys (Conference on Welfare Work, May 1, 1906). In another, New York City's buildings inspector argued worker productivity turned on access to pure air, water, and food (Conference on Welfare Work, June 12, 1906). Welfare agents at International Harvester, a Chicago-based farm machine company, reported back directly to the company's president.

In 1909, Hull House resident Laura Dainty Pelham founded the City Gardens Association (CGA), to make land available to members of the People's Friendly Club. She appealed for land and money, and received offers of lots scattered around Chicago (Pelham 1909). Harvester offered 90 acres, and the association chose to use 20 acres next to its factory. Families lined up at 
Hull House, paying \$1.50 - roughly $\$ 40$ in 2018 dollars (Williamson 2018) - to claim an eighthacre plot. The CGA acted as a broker, offering licenses to use Harvester's land. "The gardener virtually possesses a 'deed' to the land," the association reported, "but must keep its condition up to a required standard." Gardeners were "subject to dispossession when the owner wants to use the land.” (“"Back to the soil' cure” 1910)

The program fit with Harvester's approach to corporate welfare. The company had long opposed labor organizing. In 1886, a lockout outside its factory led to the Haymarket Square massacre (Green 2006: 162-173). Managers eventually began experimenting with other ways of discouraging unionization. In 1901, Harvester created a welfare bureau (Mandell 2002). The company welfare secretary, who joined the CGA board, argued that the "social and recreative life of the people [were] one of the first needs to provide for," since the "character of the employees, and conditions in neighborhoods in which they live, determine largely what an employer may do.” (Price 1907)

Harvester lost little by offering use of its land. The parcel sat next to a fork of the Chicago River rendered a stagnant swamp when a shipping canal had opened a few years earlier. Since the fork was still considered a navigable waterway, it could neither be dredged nor filled until Congress changed its status. The question was tied up in committee, leaving the future of the river, and Harvester's land, uncertain (Sanitary District of Chicago 1906: 11347-11348; Committee on Interstate and Foreign Commerce 1921-1922: 109-111).

The experiment at the Harvester Garden set a model that migrated from private to public land. In 1910, the Western Electric company offered up land; in 1912, the CGA gained access to ten acres of a family estate (“"Back to the soil' cure” 1910; "Toilers to farm” 1912). That May, the Tribune published a letter from an out-of-state subscriber, offering up vacant lots. Pelham used the letter to launch a campaign to recruit more land ("City 'farms' for the poor" 1912). By 
1913, city agencies joined the effort. The directors of Chicago's park districts discussed creating demonstration gardens. Pelham hoped these would "encourage the general utilization of waste spaces for growing vegetables." (Hyde 1913) In 1915, the city's Department of Welfare made the CGA responsible for cataloging offers of land. During a recession that year, the Sanitary District offered 3,500 acres, some of which were allotted for small farms (Hyde 1915a). Noting the successful experience of small farms near European cities, the Chicago Tribune donated money for the experiment (Hyde 1915b).

Advocates claimed that using idle land for gardens created economic value. The Tribune routinely reported the value of harvests, and of gardeners' sales of surplus produce ("Gardens for the poor lesson to women" 1909; Evans 1915). In the fall of 1909, for example, each family received enough vegetables to support itself, plus $\$ 30$ in sales; the CGA invested just $\$ 6$ per family ("A use for vacant lots" 1909). Such figures, together with the promise that gardening could reduce the costs of private charity and public relief, convinced Tribune editors that the project should be expanded. In Philadelphia and New York, poor families farmed "thousands of acres" with "splendid results," the paper observed; the "necessity for bread lines and other forms of charity have been greatly lessened." In Chicago "there are hundreds of acres," the paper noted, "which might be used for this purpose if the owners would let the association have them for a term of years." (Ibid.; "Gardening in the garden city" 1910)

Pelham, meanwhile, hoped to increase workers' leverage. Companies "know a line of laborers stand waiting, forced by their necessities to accept anything," she wrote in a letter, "and this condition is held as a club over the heads of unskilled workmen" (Carroll 1912: 219). She saw the problem of the unemployed as "a menace," arguing that companies would be less likely to lock out employees, cut wages, or fail to recognize unions "if the army of unemployed were diverted away from the congested labor centers." Publicly, Pelham reported that the Harvester 
Garden offered growers "a real taste of farm life, and almost without exception they have preferred it to work in the streets and factories. Many of these have taken to the open air and started larger farms in the country." ("Uses small farm" 1910) In later years, she dropped this claim. If enticing the unemployed away from Chicago was the aim, it never bore much fruit.

Proponents also claimed that using land for gardens cultivated moral values. Landowners were initially skeptical of Pelham's appeals, thinking "it would be impossible to start a garden because of the proclivities for 'lifting' among the boys of the neighborhood." ("City 'farms' for the poor" 1912) Pelham reported, however, that letting people use vacant land actually increased respect for property. Even without fences, "nothing is ever pilfered or damaged by hoodlums," she noted ("Gardens given to the poor" 1910). Officials from the prison across the street reported "a great change in the attitude of the residents toward other people's property since we started the gardens." ("Toilers to farm" 1912) Others saw similar effects. "In the worst neighborhoods, where small boys are encouraged to work at raising vegetables," Chicago's former commissioner of public health noted, "there is less pilfering, less stealing and less crime." (Evans 1913)

Promoters also asserted that gardens increased "industry, thrift, self-respect, selfconfidence, and honesty." (“"Back to the soil' cure" 1910) Reformers were eager to instill these values in immigrant women. The "laziness of the housewife," Thomas and Znaniecki wrote in The Polish Peasant (1920: 211), "seems to be brought about by the changes in the nature and bearing of housework." Such work in Chicago was less varied than in Poland, where it involved tending a garden. By gardening, women could "positively contribute[] to the income and property of the family." The Tribune noted approvingly that gardens were "almost like the early days, when women worked in the fields," giving them "a spirit of independence." ("A use for vacant lots" 1909; "Poor of city get 90 acres to till" 1909). 
Finally, gardens were claimed to improve health and aesthetics. The "mentally and physically unable," the CGA asserted, were improved "morally, mentally, and physically without pauperizing them.” (“"Back to the soil’ cure” 1910) Thanks to the Harvester Garden's fresh air and "soft, spongy earth," a boy reportedly gained ten pounds in a single summer ("Gardens for poor lesson to women" 1909). These benefits came as the association turned "waste places... into beautiful gardens." (“"Back to the soil' cure” 1910) One article described the Harvester Garden's "pastoral scene" as "an artistic asset for the city... [that] fits in with the scheme of the 'City Beautiful.'” (Gilbert 1914)

These claims built a case for making this form of redistribution an ongoing feature of Chicago's landscape. If letting the poor use vacant lots cultivates economic and moral value, then it follows that letting land lay idle is inefficient and unjust. Season by season, through deals with landowners, newspaper coverage, and presentations to civic groups, Pelham and others worked as norm entrepreneurs (Sunstein 1996), asserting that landowners owe a social obligation to the needy (Alexander 2009), who have a moral claim to use idle land.

By 1915, people began to imagine use-based welfare becoming permanent. If farms on sanitary district land were successful, the Tribune argued, "there is no reason why the plan cannot be carried out on a great scale in future years." ("Sanitary body quick to vote small farms" 1915) One superintendent at a Harvester factory hoped "to see every available foot of tillable soil in Chicago made available to laborers' families throughout the city without special reference to IHC families" (Reider 1915).

Then, in March of 1917, the United States entered the war in Europe. Mayor Thompson assembled business and civic leaders to build support for a citywide gardening campaign, then created a city gardens bureau in his City Hall office ("Mass meeting gives gardens a big boost" 1917). Newspapers reported widespread support among business leaders. Harvester's 
agricultural extension director, Perry Holden, declared that gardens could feed half the city, and was named to lead the campaign. City agencies identified vacant lots for public and private landowners to contribute. Police on motorcycles took soil samples. The high cost of living and threat of food shortages and riots loomed ("Gardens get mayor's room" 1917; "Business men aid garden idea" 1917; Holden 1917; "Mayor asks city heads to be farmers" 1917; "Motorcycles to aid gardens" 1917; "U.S. facing famine" 1917; "Predicts riots" 1917).

By April, officials worried that land donations were not meeting demand from gardeners, or what would be needed to avoid food shortages ("Demand very great for gardening space" 1917). A garden bureau employee, Leroy Boughner, proposed that leaving land idle be treated as a crime, even in peacetime. The city should seize vacant lots, he argued, and allow gardeners to use them without owners' permission, requiring compensation if owners destroyed gardeners' crops ("City urged to conscript lots" 1917).

Boughner's proposal resonated with longstanding theories of property. The notion that people gain rights by mixing their labor with things taken from nature was rooted in Locke's labor theory, which had previously been deployed to justify expropriating people—native Americans-who failed to put land into cultivation (Armitage 2012; Cronon 1983: 56-57). The idea that users had a moral claim to idle property also aligned with the Protestant ethic, which Weber (2001 [1930]: 104) described as opposed to "relaxation in the security of possession [and] the enjoyment of wealth with the consequence of idleness."

Boughner likely drew on his experience running a pre-war beautification campaign in Minneapolis. There, gardeners simply

took possession of the lots and settled with the owners afterward. As it turned out, a very small percentage of the owners objected to this use of their idle property, which improved it rather than otherwise, and it cost the club less to straighten it out with the few who 
objected, and to reimburse the gardeners for their loss, than it would have cost to go to all the trouble looking up the owners and securing permission in advance. ("A city full of gardens" 1916)

Given the wartime urgency, Boughner likely hoped his proposed rule would speed the matching of land with growers.

The opposite seems to have happened. Boughner's proposal to make gardening someone else's land a legal privilege (Hohfeld 1913: 30) — thereby limiting owners' right to excludewent nowhere. Business support for a city-run garden bureau evaporated. Within a week, the Chicago Association of Commerce and Industry moved the bureau out of City Hall, and into its own offices. The new director wondered if Chicagoans would "understand that we refer to each of them individually and to their own yards and lawns when we say, 'Grow a garden."' (“Association of commerce as garden chief" 1917 (emphasis added)). By early June, the campaign was shuttered, ostensibly for lack of funding ("Garden bureau closed by commerce board" 1917). Holden, however, noted that money was in fact raised, and seeds purchased. ${ }^{4}$

A renewed attempt to make gardens a permanent feature of Chicago's landscape came soon after the war. In 1918, the commissioners of Chicago's West Park District asked landscape architect Jens Jensen to develop a plan for expanding the city's parks. Jensen had designed the Harvester Garden and sat on the CGA board. He drew up a plan for a network of parks, including a municipal farm and a dozen market gardens (West Chicago Park Commissioners 1920). Jensen

\footnotetext{
${ }^{4}$ Holden's annotation appears next to the article "Lack of funds may end garden bureau," Chicago Herald, May 15, 1917, in the "Chicago garden campaign" scrapbook, p. 115. Perry G. Holden Papers, Michigan State University Archives.
} 
modeled these on the Harvester Garden, which he relabeled an "existing municipal garden." $\mathrm{He}$ called for taking private land using eminent domain, creating public land for gardeners to use.

At a meeting to approve Jensen's plan, one commissioner promised the cost would be "surprisingly low," since the land plotted out included few obstacles ("Chicago to be Just One Park After Another" 1919). Yet Jensen simply hadn't made obstacles apparent. He had, for example, included a photo of Harvester's property, captioned simply as vacant land "to be condemned for parks." Within months, Jensen and the entire board of commissioners had been fired. Jensen (1990 [1939]: 94) later reflected that "Chicago was once called a garden city," asking, "What has become of the gardens?" He explained: "What has happened in Chicago has happened in many other large cities where speculation has been the guiding force."

The moral and legal principles behind Boughner and Jensen's proposals had deep roots, but ran up against something more powerful. These attempts to make land use for gardens a permanent urban institution — whether by formalizing a social obligation norm, or through eminent domain—were swiftly and decisively blocked by people interested in preserving the exchange value of land (Logan and Molotch 1987). Newspapers had long promoted garden programs, but when business leaders moved to close the garden bureau, there were neither editorials protesting the move, nor reports of protests by would-be gardeners. Despite settlement movement leaders' support for Jensen's plan, there do not seem to have been protests when it was blocked. This could, of course, reflect either a lack of social movement pressure for continued access to land, or a willingness among newspaper editors to drop a cause that they had previously championed. In either case, it appears that when promoters of reallocating rights to use Chicago's vacant lots were met with resistance from landowners and the business community, the practice they developed on a temporary basis failed to generate alliances or coalitions that might have mobilized to defend it as a lasting institution. 


\section{Relief Gardens, 1931-1935}

Faced with an economic crisis in the fall of 1929, companies and government officials around the country again turned to gardens to support the unemployed (Lawson 2005). Gardening was not a major form of relief the following summer, but by the spring of 1931 firms and government agencies in Chicago and elsewhere had launched programs (Colcord and Johnston 1933: 9). Promoters realized they were reviving a bygone practice. "It was during the period of the World War," one Harvester employee (incorrectly) recalled, that "the garden project as applied to industrial workers and the non-farming population first attracted attention." As he saw it, the return to gardening reflected a renewed "need for the elemental sustaining products of the soil." (Hawkins N.D.)

With the City Gardens Association no longer in existence, Chicago's firms and government officials experimented with new ways to match growers with land. ${ }^{6}$ They made three main changes. First, they brokered land access themselves, rather than partnering with community-based organizations. Next, firms provided gardens for their own laid-off workers, rather than residents generally. Finally, government agencies framed this form of welfare provision as a temporary measure, rather than the beginning of a more permanent reworking of property and economic relations.

Harvester emerged as a leader in company gardening, both in Chicago and nationwide (U.S. Department of Commerce 1932). In February 1931, the company coordinated discussions

\footnotetext{
${ }^{5}$ Potter, Paul (1931) “Home Gardens Again Favored as in War Days.” CDT, May 3.

${ }^{6}$ Pelham died in 1924; Jensen, after being fired by the park district, turned to work for private clients.
} 
of gardens during work-council meetings in all of its factories. A garden committee at Chicago's McCormick Works plant surveyed active and laid-off employees, and looked for suitable land (Ibid.) Harvester rented several fields around the city, which it plowed, fertilized, divided into plots, and allotted to workers' families. By 1932, it had made available 1,000 acres for gardens in and around Chicago, and another 1,200 acres elsewhere around the country ("Harvester's relief and garden plans" 1932).

Harvester maintained tight oversight. Its extension department distributed seed packets and plans for planting; only crops that could be canned were permitted. People on public cash relief received seeds for free, but people receiving Harvester's unemployment relief loans were charged. Gardening gave a worker "an outlet for his latent activity," and helped Harvester keep him integrated into its management hierarchy (Hawkins N.D.). Organizers assigned gardeners to fields supervised by the foremen under whom they had previously worked. Foremen enforced the extension department's instructions. "Each gardener must care for his plot in a way satisfactory to those in charge," an article in the company magazine noted. "Neglect is not tolerated." ("Harvester's relief and garden plans" 1932)

For Harvester, the gardens created economic benefits. An internal memo noted that by supplementing other unemployment relief, gardens reduced the direct burdens of relief upon both the company and employees. Before they could receive loans or allowances from the Harvester relief fund, employees had to apply for a garden (“Confidential memorandum" 1932). Income supports were made contingent on use-based welfare.

Harvester's magazine and internal memos stressed the gardens' non-economic value. The need for employee gardens "goes deeper than the mere monetary value of the foodstuffs raised," one memo observed. "It reaches down to supply an equally real need in the mental and moral life of the worker, namely that of furnishing a healthful activity to take the place of the vacuum 
created by his lack of work in the factory." ("Industrial relations policies" N.D.) Gardens helped prevent "the despair and discouragement that is particularly dangerous to the morale of not only the workers and their families but also of the community as a whole." (Ibid.) Together with other company welfare programs, the hope was that gardens would reinforce "the basic elements of harmony and cooperation in industry." (“Confidential memorandum" 1932)

For Cyrus McCormick Jr. (1932: 64), Harvester's past president, the gardens inspired visions of a new alliance between labor and capital. If gardens became permanent, employees could "work on the land for food as well as at their jobs for wages." A Harvester plant manager, however, was more realistic. "Most of them couldn't be turned into part-time truck gardeners, even if you gave them the tools and the land free," he noted. "Let them get back to the regular pay envelope and they won't ever look at a hoe again.” (Miller 1932)

Harvester's experiments fed into broader thinking about social policy, and possible alternative alliances. After the garden's first season, Harvester's president joined a committee of industry and labor leaders to discuss unemployment relief and report to President Hoover. They met in Chicago, immediately after the Illinois Manufacturers Association released a report declaring voluntary, company-run relief projects to be preferable to state-mandated unemployment insurance ("Job committee named by Hoover" 1931). According to the committee chairman, the goal was "jobs, not the dole;" industry would address the economic crisis as "a matter of enlightened self-interest." (Kinsley 1931) This approach played to President Hoover, who was keen to promote self-help, and reluctant to involve the federal government in welfare provision (Katz 1996: 222). The committee report to Hoover called for "a special emergency measure"- surveying "the possibility for transfer of surplus labor from cities to farms, on a work-for-keep and/or other basis, with a view to... relieve pressure upon urban relief agencies." (President's Organization on Unemployment Relief 1931) 
The next spring, Harvester began advising officials in Chicago on how to set up public relief gardens ("Plan gardens for jobless" 1932; "Start plowing 3,000 acres” 1932). The Cook County subsistence garden service took the lead. Public agencies and private owners donated land on the city's outskirts. Harvester provided five tractors. In 1932, the service made available 1,121 plots; by 1935, this had increased to nearly 9,000 (Cook County Subsistence Garden Service 1935; Gardener 1935). The county also ran a farm where men from Chicago's shelters grew food for their shelters' kitchens.

Allotting land to gardeners was not costless. Finding gardeners created a burden for relief agencies, so the garden service shifted its own staff from preparing plots to recruiting relief recipients. For use of a plot, people had $\$ 9$ deducted from their relief allowance; in 1935 this was cut to $\$ 4$. Getting people to the gardens became the single biggest expense: the service paid for transit fare, and arranged vehicles to take growers from the end of rail lines to the fields. Yet even as the garden service reduced barriers, growers still "defaulted" on their plots, failing to complete planting.

Nevertheless, the service saw the gardens as a good investment. Officials meticulously tallied their value. For 1934, they estimated that the total value of garden produce, at wholesale prices, was $\$ 69,799.22$ - or about $\$ 1.25$ million, in 2018 dollars (Cook County Subsistence Garden Service 1935: 25; Williamson 2018). Each dollar invested produced $\$ 2.74$ worth of food.

The service focused on how gardens boosted morale. In the 1934 annual report, economic figures were buried at the back. The report opened with stories of hope and joy: a widow who "forgot myself and my troubles"; a "colored man" who said it was hard at first, "but the ha'vest in fall made it wo'th wo'king fo"'; a German gardener who exclaimed "it was so good to work in the soil." The report proposed opening more farms, to "aid in solving the morale problem" of the thousands living in shelters. 
As before, the gardens fed hopes that unemployed workers might be inspired to leave the city. As president-elect, Franklin Roosevelt observed that a migration of millions of the urban unemployed to the country might be needed to end the economic crisis ("City idle must go to country" 1933). In response, Chicago's civic leaders pitched grand plans. One proposed that taxdelinquent rural farmers cede title to ten or twenty acres, which the state could allot to urban workers on a rent-to-own basis (Kinsley 1933). Another argued for resettling some of Cook County's 800,000 relief recipients to homesteads just outside the city, allowing them to still seek part- or full-time work (“Chicago considers land colonization plan" 1933). William Dodd (1933), a prominent University of Chicago history professor, observed in the Tribune that "free lands" had repeatedly been the solution to mass unemployment before 1900, when the frontier was closed. The state could effectively create a new frontier, he noted, and allow the unemployed to again leave cities for the country.

These plans drew critics. An agricultural economist argued in the Tribune that competition from homesteaders would bankrupt commercial growers, turning them into peasants (Hibbard 1933). Another letter to the editor agreed: homesteaders on ten acres "would be reduced to working by hand," marking "the first step toward American peasantry." (Davis 1933) Yet with the creation in 1934 of the federal subsistence homesteading program, it appeared, at least briefly, that allotting gardens to unemployed Chicagoans might help spark a migration to the country. "For the successful relief gardener," the county gardens service (1934: 44) noted, a plot "may well become the proving ground for him to take a subsistence homestead."

Even as new alliances and visions were emerging to use gardens as a stepping stone to shift the unemployed out of the city, they faced opposition from rural growers. The garden service's 1934 report opened with a letter from U.S. Agriculture Secretary Henry Wallace to the Vegetable Growers Association of America. Wallace explained that although vegetable farmers 
faced surpluses, several million families were out of work, out of money, and suffering for lack of food. Wallace assured commercial growers that relief gardeners did not have much purchasing power. "What few fresh vegetables they can raise in their free time," he wrote, "help out their food problem without affecting the market for your growers practically at all." Moreover, the government prohibited sales of garden produce. "This whole movement is to be viewed as an emergency proposition," he concluded; "when the emergency is over, most of these families will probably go out of the gardening and will be buyers of more fresh vegetables than before." The past offered a guide: "That was the way it worked out after the war, and that is doubtless the way it will work this time." (Ibid. 43)

In 1935, Cook county's gardens drew more growers than ever. The Depression's worst years had passed, but unemployment rates remained dire. Nationally, unemployment had fallen to around $20 \%$ in 1935 , from a peak of nearly $25 \%$ a few years earlier (Lebergott 1948). In Chicago, African-American unemployment remained particularly bad. Nearly half of AfricanAmerican domestic servants, one third of semi-skilled workers, and one quarter of the unskilled remained jobless in 1935 (Drake and Caton 2015 [1945]: 217).

Nevertheless, state officials abruptly canceled garden projects. Early in 1935, Congress had appropriated money for a federal relief program, and President Roosevelt created the Works Progress Administration. This would replace the Federal Emergency Relief Agency, which had provided federal aid for state and local gardening programs. The WPA had grand plans for Chicago: spending $\$ 32$ million to build 1,000 miles of road, creating jobs for 108,000 people on county relief rolls ("Order WPA staff geared up" 1935). In September, the Illinois Emergency Relief Committee met and eliminated subsistence garden programs, "in view of the employment program of the WPA." ("Relief economy shakeup" 1935) 
The end of public support for relief gardens reflected broader trends. Under Roosevelt, the federal government was taking a rapidly-expanding role in funding and coordinating relief (Katz 1996: 224-28). This included the creation of federally-funded relief jobs, which made locally-coordinated use-based welfare projects appear unnecessary. Rather than give the unemployed access to land, local governments would instead contribute land for federallyfunded infrastructure projects. Moreover, federal agencies had begun experimenting with using surplus agricultural commodities as welfare supports (Finegold 1988). This helped both rural producers and urban consumers who might otherwise oppose higher food prices. In 1937, when the program that would become known as food stamps was created, all remaining federal funding for relief gardens was cut (Lawson 2005: 160). Use-based welfare had reemerged and blossomed under Hoover. But with Roosevelt's creation of federally-funded income supports, this local form of social provision once again dried up and disappeared.

\section{Discussion}

When both land and laborers are laying idle, conditions are ripe for efforts to bring them together. Use-based welfare has emerged when social reformers created programs to broker land access, granting the poor the ability to use vacant land. This has required gaining the cooperation of property owners - often through assurances that such schemes will be voluntary, temporary, and cost-saving.

The Chicago case illustrates how use-based welfare has been posed as both a complement and a substitute for income supports. Promoters promised that by letting the needy use land, projects could reduce reliance on public relief. Although Harvester briefly conditioned eligibility for income supports on growing a garden, public garden projects in Chicago differed from other cities in that they never created such a condition. Ultimately, when the federal government 
expanded income supports, this was seen as a substitute for reallocating the use of land, and public relief gardens disappeared from Chicago's landscape.

The Chicago case also illustrates how a limited experiment can scale up. Successful private charity projects led to offers of land from other private owners, then to use of public land. Responsibility for coordinating garden projects migrated from private organizations to municipal agencies. In the process, the work requirement and supervision integral to use-based welfare also migrated from private and corporate relief projects — where they might be expected - to become part of public welfare programs. As the practice of sharing land use spread, promoters came to see temporary, experimental projects as first steps toward entrenching use-based welfare as a permanent social policy institution and an enduring feature of the urban landscape.

The experience in Chicago suggests reasons why use-based welfare, unlike other forms of social policy, has failed to become entrenched. Three factors stand out. First, it was challenging to implement projects that reallocated the use of land. Second, attempts to decommodify land and food met opposition. Finally, reformers failed to mobilize a movement to defend land access. I address each factor in turn.

\section{Implementation Challenges}

Letting the unemployed use idle land might seem straightforward. If an owner isn't using land, why shouldn't others? Get permission from owners, and let the needy start planting gardens. Or, as Boughner might suggest, don't ask permission, and start planting anyway.

Yet this mode of redistribution has significant costs and challenges. Even during downturns, land is scarce. Searching for available land, locating owners, and gaining permission takes time and effort. Available land might not be near potential users. It may need 
improvements to be suitable for agriculture. Matching land with gardeners can entail costly transportation subsidies.

Recruiting gardeners could also be challenging. This wasn't the case for Hull House, where people lined up to claim the few hundred available gardens. But during the Depression, county officials struggled to attract thousands of gardeners to plots on Chicago's outskirts.

Organizers couldn't always assume people knew how to grow food. The City Gardens Association found that immigrants from Italy or Bohemia had growing skills. During the Depression, however, many prospective gardeners had to be trained. Insufficient supervision could increase the risk that investments in seeds and land would go to waste.

Requiring the needy to work the land also created challenges. Other than their focus on European immigrants (cf. Fox 2010), the fact that private relief involved a work requirement was, for the Progressive Era, not atypical. During the Depression, a work requirement and supervision made sense for firms like International Harvester, which aimed not only to cut the costs of relief but also to keep laid-off employees in the company fold and working under foremen.

But when use-based welfare migrated to public relief projects, the work requirement created problems. The county gardens service struggled to keep gardeners from abandoning their plots. Gardening was hard work, which many gardeners apparently came to see as more burden than benefit. Unlike elsewhere, in Chicago gardening was not required to be eligible for cash benefits. Gardeners could abandon their plots and only lose the fee deducted from their benefits, rather than losing cash benefits entirely.

Getting the needy to support themselves appealed to Chicago's social reformers and relief officials. But use-based welfare proved difficult in practice. Given the costs and challenges of 
redistributing the use of land, one can appreciate why relief officials and policymakers might find income-based supports funded through tax and transfer more appealing.

\section{Opposition}

Use-based welfare threatens the status of land and food as commodities. During both the Progressive Era and the Great Depression, this did not initially provoke opposition—-privatelycoordinated projects were considered experimental and temporary. This created momentary alliances between landowners and social reformers. These experiments inspired visions of how new forms of cooperation might reshape relations between firms and employees, or between landowners, the unemployed, and relief agencies. But ultimately, despite these visions-from Pelham and Tribune editors to Cyrus McCormick and Hoover's committee of business leaders-

these alternative alliances unraveled, without producing the type of policy feedback that in other contexts has produced enduring institutions (Weir et al. 1988).

Instead, just when experiments began to transform into publicly-coordinated relief programs, and to inspire visions of permanent use of land to support the poor, they met opposition. In part, this opposition confirms what an urban sociologist might expect. Temporary projects may be promoted as ways to avoid increased taxation, by preventing reliance on public relief. But to do this in the long term invites attempts to entrench and institutionalize use-based welfare. That means adjusting property rules, either to make some private land permanently public (as in Jensen's plan), or to restrict all private owners' right to exclude (as in Boughner's proposed rule). Such proposals to decommodify land can trigger pushback from an urban growth coalition (Logan and Molotch 1987) — the constellation of actors, including elected officials, landowners, and newspapers, invested in increasing land values. 
The experience of the Great Depression points to another source of opposition-which might be missed by focusing on cities, but overlooking their links to the country (Williams 1973; Angelo and Wachsmuth 2015). Large-scale relief gardens intervene in the political economy of food. Individuals and groups representing rural growers feared Depression-era gardens would destabilize already-precarious agricultural markets, both by offering food outside the market and by inspiring plans to lure the urban unemployed to the country. During this period, opposition primarily came from rural producers, not urban landowners and their allies. The substitution of new supports funded by tax and transfer returned urban residents to their role as consumers, shoring up the market for agricultural commodities.

\section{Non-Mobilization}

Although initial experiments scaled up and inspired visions of a new, permanent form of support for the poor, no movement seems to have appeared to defend land access when plans faced opposition. Labor and social movement pressure have been key to institutionalizing other forms of social policy, helping both realize new rights and entrench existing ones by reshaping beneficiaries' preferences and policymakers' sense of the politically feasible. Why was the experience of use-based welfare in Chicago different?

Several factors likely hampered mobilization. First, as mentioned above, many gardeners appear to have been ambivalent. They did not eagerly move to the country, as Pelham hoped. Managers at Harvester acknowledged that if laid-off workers could again earn a salary, they would happily leave their hoes behind. County officials struggled to keep gardeners from abandoning their plots. Ambivalence is not fertile ground for growing a social movement.

Nor did labor unions champion garden projects. Indeed, Harvester supported gardens precisely because they aligned with its corporate welfare policy_-designed to preempt labor 
organizing (Katz 1996: 92-97). Pelham's dream of increasing labor power didn’t bear fruit, and she doesn't appear to have found allies in organized labor.

Finally, the legal relationship at play in use-based welfare likely undercut the potential for mobilization. Proponents of use-based welfare acted as brokers, asking landowners to grant gardeners a license to use their property. This contrasts with mobilizing popular pressure to demand rights and resources from the state. In Chicago, the people who took on the role of broker were often elite social reformers (such as Laura Dainty Pelham), or representatives of owners themselves (such as company welfare bureaus). The success of any particular deal turned on a landowner's agreement to grant use of a specific parcel. This may have dissuaded brokers from acting as organizers: popular pressure to maintain land access might have made landowners skittish. Pelham, recall, had to assuage landowners' concerns that letting the needy use land would encourage disrespect for property. During neither period did brokers appear to mobilize gardeners to lobby for continued political support for land access - a mechanism by which contemporary reformers have maintained funding for social services (Marwell 2004) and the poor have secured use of public land in Latin American cities (Holland 2017).

The fact that urban gardening can be scaled up through deals brokered by well-connected social reformers, rather than through popular demands, may mean that when use-based welfare faces opposition, there is no existing movement or constituency ready to defend the privilege to use land. Compared to other forms of social policy that emerge through popular demands for rights, this could make use-based welfare less likely to have a ratchet effect, and more susceptible to retrenchment.

Taken together, the challenges of implementing use-based welfare, along with its natural opponents and stumbling blocks to mobilization, help to explain why it has repeatedly failed to become an enduring urban institution. Since the Great Depression, income supports and social 
services have dominated the field of social policy. We no longer conceive of access to resources, particularly land, as a form of redistributive social policy.

In parts of Chicago and other U.S. cities, however, conditions appear ripe for the reemergence of use-based welfare. High rates of unemployment and poverty, together with an abundance of vacant lots, resemble conditions that have historically prompted a turn to this longstanding form of social policy. In Chicago's Englewood neighborhood, for example, recent surveys suggest nearly half of households live in poverty, and over one-third of adults are unemployed (City of Chicago Data Portal 2016; Illinois Action for Children 2016). Meanwhile, the city counted some 4,500 vacant lots in the neighborhood (City of Chicago 2014: 12). In 2014, the city council designated Englewood as Chicago's first urban agriculture district. This has focused city agencies and local foundations on finding land for farms that will offer job skills training for the unemployed, and the possibility for urban farmers to earn supplemental income.

To make land available to growers, promoters of urban agriculture are again experimenting with property. In 2011, Chicago amended its zoning code to permit large-scale commercial farming. A land trust created to protect community gardens has expanded its mission, and now leases vacant lots to nonprofit farms (Ela 2016: 282-84). Organizers in Englewood have created a new community land trust to lease land to for-profit farmers (Urban Farm Pathways Project 2015).

History, of course, is not simply repeating itself. Projects today are cropping up in an urban terrain that has transformed radically since the Great Depression. Rather than suffering temporary setbacks due to economic recessions, neighborhoods like Englewood have lost jobs and residents for decades, as a result of deindustrialization and the flight of first whites and then African-Americans to the suburbs. The organizational and institutional forms cropping up in this landscape — social enterprise farms, together with zoning and land trusts for urban agriculture- 
propose to make farms an enduring feature of neighborhoods where investment in housing, commerce, and industry has largely dried up.

This apparent return to use-based welfare, though still nascent, aligns with decades of efforts to reform and restrict the welfare state. This reform project has created work requirements for income supports and social services; sought to restrain federal funding for welfare supports; and turned on a renewed argument that reliance on welfare leads to immorality and dependence. As federal politicians seek to restrain federal support for income-based welfare, use-based welfare offers municipal reformers a means of supporting the poor and redistributing resources while making them contingent on work. The shift from federal to local supports is paired with a shift from public relief toward social support delivered by private nonprofit organizations, which receive both grants and free public land.

While the institutions and organizations of contemporary urban agriculture are new, the legal and political-economic instinct is familiar: achieve redistribution by reallocating the right to use and benefit from land, rather than via tax and transfer. The reemergence of use-based welfare frames it as a complement, rather than a substitute, to other supports. Today's urban farms are not imagined as a means of subsistence, or an alternative to income supports. Instead they are proposed as sites for summer programming for at-risk youth, and job training for the unemployed, as part of efforts to help people support themselves through employment, rather than rely on social assistance.

Is use-based welfare a social policy path not taken? One might read the shift to federallyfunded income supports in 1935 as a definitive shift to redistribution grounded in tax and transfer. Yet while use-based welfare has repeatedly failed to become entrenched, it has also repeatedly re-emerged. It may be doing so again today, as reformers in Chicago and beyond look to use land as a support for the urban poor and unemployed. Recognizing the longstanding and 
ongoing interconnections between social policy and land use challenges sociologists to see beyond the horizons of disciplinary subfields. Doing so offers a new perspective on how urban institutions have supported diverse forms of redistributive social policy — and points to parallels between a longstanding practice and ongoing transformations to the landscapes of American cities. 


\section{Archival Sources}

Michigan State University Archives, Perry G. Holden Papers.

The "Chicago garden campaign" scrapbook, kept by Holden and his staff, includes the newspaper articles from 1917 and 1918, listed below.

Wisconsin Historical Society, McCormick-International Harvester collection

Conference on Welfare Work at Chicago Commons, Minutes of the Fifth Meeting, May

1, 1906. Series 2C, Box 40.

Conference on Welfare Work at Chicago Commons, Minutes of the Eleventh Meeting, June 12, 1907. Series 2C, Box 40.

Confidential memorandum concerning relief activities of the International Harvester Company, June 1, 1932. McCormick Collection, Box 714.

"Industrial relations policies of the International Harvester Company.” N.D. McCormick Collection, Box 714.

\section{Anonymous Newspaper and Magazine Articles}

“A city full of gardens.” Country Life in America, May 1916: 90-96, 93-94.

“A use for vacant lots.” Chicago Daily Tribune, October 21, 1909.

“Association of commerce as garden chief.” Chicago Daily Tribune, May 2, 1917.

“"Back to the soil' cure.” Chicago Daily Tribune, June 5, 1910.

“Business men aid garden idea.” Chicago Herald, March 23, 1917.

“Chicago considers land colonization plan.” New York Times, April 9, 1933.

"Chicago to be Just One Park After Another." Chicago Daily Tribune, November 27, 1919.

“City 'farms' for the poor.” Chicago Daily Tribune, May 26, 1912.

“City idle must go to country: F. D. Roosevelt.” Chicago Daily Tribune, January 17, 1933. 
“City urged to conscript lots for gardeners." Chicago Daily Tribune, April 18, 1917

“Demand very great for gardening space." Chicago Post, April 18, 1917.

"Gardening in the garden city." Chicago Daily Tribune, January 4, 1910.

“Gardens for the poor lesson to women." Chicago Daily Tribune, October 20, 1909.

“Gardens get mayor's room.” Chicago News, March 21, 1917.

"Gardens given to the poor." Chicago Daily Tribune, April 4, 1910.

“Harvester's relief and garden plans." Industrial Relations 3 (8): 398-402, August 1932.

"Job committee named by Hoover will meet today." Chicago Daily Tribune, September 28, 1931.

"Lack of funds may end garden bureau." Chicago Herald, May 15, 1917.

"Mass meeting gives gardens a big boost." Chicago News, March 16, 1917.

"Mayor asks city heads to be farmers." Chicago American, April 18, 1917.

"Motorcycles to aid gardens." Chicago Journal, April 2, 1917.

“Order WPA staff geared up for rush of work." Chicago Daily Tribune, September 14, 1935.

“Poor of city get 90 acres to till.” Chicago Daily Tribune, March 24, 1909.

“Plan gardens for jobless in county forests." Chicago Daily Tribune, April 20, 1932.

"Predicts riots." Chicago Daily Tribune, April 14, 1917.

"Sanitary body quick to vote small farms." Chicago Daily Tribune, March 19, 1915.

"Start plowing 3,000 acres for relief gardens." Chicago Daily Tribune, May 6, 1932.

“The people’s friendly club.” Hull House Bulletin VII (1): 14 (1905-1906).

“Toilers to farm empty city lots.” Chicago Daily Tribune, April 15, 1912.

"U.S. facing famine, is warning." Chicago American, April 4, 1917.

"Uses small farm to lure city people to country." Chicago Daily Tribune, March 21, 1910.

“World improves, says Kropotkin.” Chicago Daily Tribune, April 18, 1901. 


\section{References}

Ackerman, Bruce, and Anne Alstott (2000) The Stakeholder Society. New Haven, CT: Yale University Press.

Alexander, Gregory (2009) “The social-obligation norm in American property law.” Cornell Law Review 94 (4): 745-819.

Allard, Scott W., and Mario L. Small (2013) "Reconsidering the urban disadvantaged: The role of systems, institutions, and organizations." ANNALS of the American Academy of Political and Social Science 647: 6-20.

Allen, Patricia (2008) "Mining for justice in the food system: Perceptions, practices, and possibilities.” Agriculture and Human Values 25: 157-161.

Angelo, Hillary, and David Wachsmuth (2015) “Urbanizing urban political ecology: A critique of methodological cityism.” International Journal of Urban and Regional Research 39 (1): $16-27$.

Armitage, David (2012) “John Locke: Theorist of empire?” in Sankar Muthu (ed.) Empire and Modern Political Thought. Cambridge: Cambridge University Press: 84-111.

Avrich, Paul (1980) "Kropotkin in America.” International Review of Social History 25 (1): 134.

Bartley, Tim (2007) "Institutional emergence in an era of globalization: The rise of transnational private regulation of labor and environmental conditions.” American Journal of Sociology 113(2): 297-351.

Burchardt, Jeremy (2002) The Allotment Movement in England, 1793-1873. London: The Royal Historical Society.

Bureau of Associated Charities (1898) Fourth Annual Report. 
Bynner, John, and Sofia Despotidou (2001) “The effects of assets on life chances.” London:

Center for Longitudinal Studies, Institute for Education.

Bynner, John, and Will Paxton (2001) The Asset-Effect. London, UK: Institute for Public Policy Research.

Carroll, Charles E (1912) “Industrial peace through social justice.” Master's thesis, University of Nebraska, Lincoln.

Cho, Esther Y (1999) "The effects of assets on the economic well-being of women after marital disruption." Center for Social Development Working Paper No. 99-6, Saint Louis, MO: Center for Social Development, Washington University in Saint Louis.

Cialdella, Joseph Stanhope (2014) “A landscape of ruin and repair: Parks, potatoes, and Detroit's environmental past, 1879-1900.” Michigan Historical Review, 40 (1): 49-72.

City of Chicago (2013) “A Recipe for Healthy Places.”

City of Chicago (2014) "Green healthy neighborhoods."

City of Chicago Data Portal (2016) "Census data: Selected socioeconomic indicators in Chicago, 2008-2012.”

Coase, Ronald H (1960) “The problem of social cost.” Journal of Law and Economics 3: 1-44.

Colcord, Joanna C., and Mary Johnston (1933) Community Programs for Subsistence Gardens. New York: Russell Sage Foundation.

Committee on Interstate and Foreign Commerce, U.S. House of Representatives (1921-1922) Hearings on H. R. 9049, H. R. 8648, and S. 3177, Declaring Portions of the Chicago River to be Non-Navigable. $67^{\text {th }}$ Congress, Second Session, December 15, 1921; May 19, 1922; October 6 and 7, 1922.

Commons, John R (1893) The Distribution of Wealth. New York: MacMillan.

Cook County Subsistence Garden Service (1935) Annual Report 1934. February 7, 1935. 
Cronon, William (1983) Changes in the Land: Indians, Colonists, and the Ecology of New England. New York: Hill and Wang.

Cronon, William (1991) Nature's Metropolis: Chicago and the Great West. New York: W.W. Norton.

Dauber, Michele Landis (2013) The Sympathetic State: Disaster Relief and the Origins of the American Welfare State. Chicago, IL: University of Chicago Press.

Davis, H.G. (1933) "Peasantry.” Chicago Daily Tribune, February 14.

de Soto, Hernando (2000) The Mystery of Capital: Why Capitalism Triumphs in the West and Fails Everywhere Else. London: Bantam.

Dodd, William E. (1933) “Back-to-the-land?” Chicago Daily Tribune, March 19.

Drake, St. Clair, and Horace R. Caton (2015) [1945] Black Metropolis: A Study of Negro Life in a Northern City. Chicago: University of Chicago Press.

Earl, Jennifer, Andrew Martin, John D. McCarthy, and Sarah A. Soule (2004) "The use of newspaper data in the study of collective action.” Annual Review of Sociology 30: 65-80.

Ela, Nate (2016) “Urban commons as property experiment: Mapping Chicago’s farms and gardens.” Fordham Urban Law Journal 43 (2): 247-294.

Emirbayer, Mustafa (1997) "Manifesto for a relational sociology." American Journal of Sociology 103(2): 281-317.

Esping-Anderson, Gosta (1990) The Three Worlds of Welfare Capitalism. Princeton, NJ: Princeton University Press.

Evans, W.A. (1913) "Farming in the city.” Chicago Daily Tribune, May 25.

Evans, W.A. (1915) “How to keep well.” Chicago Daily Tribune, May 25.

Fels, Mary (1920) Joseph Fels: His Life-Work. London: George Allen \& Unwin. 
Finegold, Kenneth (1988) “Agriculture and the politics of U.S. social provision: Social insurance and food stamps." In Weir, Margaret, Ann Shola Orloff, and Theda Skocpol (eds.) The Politics of Social Policy in the United States. Princeton: Princeton University Press: 88122.

Flyvberg, Bent (2006) “Five misunderstandings about case-study research.” Qualitative Inquiry 12: $219-245$.

Fox, Cybelle (2010) “Three worlds of relief: Race, immigration, and public and private social welfare spending in American cities, 1929." American Journal of Sociology 116 (2): 453502.

Gallagher, Mari (2006) "Examining the impact of food deserts on public health in Chicago." Chicago: Mari Gallagher Research \& Consulting Group.

Gardener, Virginia (1935) “Speed planting in 900 acres of relief gardens." Chicago Daily Tribune, June 1.

Gilbert, Paul T. (1914) “Vacant lot gardening.” Western Christian Advocate, September 16.

Green, James (2006) Death in the Haymarket. New York: Pantheon.

Hale, Robert Lee (1923) “Coercion and distribution in a supposedly non-coercive state." Political Science Quarterly 38: 470-478.

Hall, Bolton (1908) A Little Land and a Living. New York: Arcadia Press.

Hawkins, L.A. (N.D.) "Harvester Employe Garden Project.” Wisconsin Historical Society, McCormick-International Harvester collection, Box 738.

Haydu, Jeffery (1998) "Making use of the past: Time periods as cases to compare and as sequences of problem solving.” American Journal of Sociology 104 (2): 339-71.

Hibbard, Benjamin Horace (1933) “Back to the land?" Chicago Daily Tribune, June 18. 
Hohfeld, Wesley (1913) "Some fundamental legal conceptions as applied in judicial reasoning." Yale Law Journal 23: 16-59.

Holden, P.G. (1917) "Gardens on vacant lots could feed half of city." Chicago Examiner, March 7.

Holland, Alisha C (2017) Forbearance as Redistribution: The Politics of Informal Welfare in Latin America. Cambridge, UK: Cambridge University Press.

Huber, Evelyn, and John D. Stephens (2001) Development and Crisis of the Welfare State: Parties and Policies in Global Markets. Chicago: University of Chicago Press.

Hyde, Henry M. (1913) “Sample gardens in public parks for city 'farmer,” Chicago Daily Tribune, October 3.

Hyde, Henry M. (1915a) "Plans to put idle on farms are under way." Chicago Daily Tribune, February 18.

Hyde, Henry M. (1915b) "Sanitary body quick to vote small farms." Chicago Daily Tribune, March 19.

Illinois Action for Children (2016) "Key indicators of need for Chicago communities." www.actforchildren.org/wp-content/uploads/2016/04/CCA-Community-ProfilesCombined-Spring-2016.pdf (accessed July 6, 2018).

Jefferson, Thomas (1986 [1785]) Letter to James Madison, October 28, 1785. In Philip B. Kurland and Ralph Lerner (eds.) The Founders' Constitution. Chicago: University of Chicago Press.

Jensen, Jens (1990 [1939]) Siftings. Baltimore, MD: Johns Hopkins University Press.

Katz, Michael B (1996) In the Shadow of the Poorhouse: A Social History of Welfare in America. New York: BasicBooks. 
Kinsley, Philip (1931) "Jobs not dole, slogan as Hoover group debates relief measures in Chicago.” Chicago Daily Tribune, September 29.

Kinsley, Philip (1933) “General Bolles offers plan for retreat to land.” Chicago Daily Tribune, February 10.

Kropotkin, Pëtr (1912 [1898]) Fields, Factories and Workshops. London: Thomas Nelson \& Sons.

Lawson, Laura J (2005) City Bountiful: A Century of Community Gardening in America. Berkeley: University of California Press.

Lebergott, Stanley (1948) “Labor force, employment, and unemployment 1929-39: Estimating methods." Monthly Labor Review 67 (1): 50-53.

Levitsky, Sandra (2014) Caring for Our Own: Why There is no Political Demand for New American Social Welfare Rights. New York: Oxford University Press.

Locke, John (1980 [1690]) Second Treatise of Government. C.B. Macpherson (ed.). Indianapolis: Hackett.

Logan, John, and Harvey Molotch (1987) Urban Fortunes: The Political Economy of Place. Berkeley, CA: University of California Press.

Lyson, Helena C (2014) "Social structural location and vocabularies of participation: Fostering a collective identity in urban agriculture activism.” Rural Sociology 79 (3): 310-335.

Mandell, Nikki (2002) The Corporation as Family: The Gendering of Corporate Welfare, 18901930. Chapel Hill: University of North Carolina Press.

Marwell, Nicole (2004) "Privatizing the welfare state: Nonprofit community-based organizations as political actors.” American Sociological Review 69: 265-91. 
Marx, Karl (1975 [1842]) "Proceedings of the sixth Rhine province assembly. Third article.

Debates on the law on thefts of wood." In Karl Marx and Frederick Engels: Collected Works, vol. 1. New York: International Publishers, 1975.

McClintock, Nathan (2013) "Radical, reformist, and garden-variety neoliberal: Coming to terms with urban agriculture's contradictions." Local Environment. DOI:

$10.1080 / 13549839.2012 .752797$.

McCormick, Jr., Cyrus (1932) “Productive gardens for the unemployed.” House \& Garden 63 (6): 52-53, 63-64.

Miller, Ronald (1932) “It's harvest time for Chicago's new army of city farmers.” Sunday Illustrated Times, October 9.

Mortensen, Dale T. (1988) “Matching: Finding a partner for life or otherwise.” American Journal of Sociology 94 (Supplement): S215-S240.

Nilsen, Micheline (2014) The Working Man's Green Space: Allotment Gardens in England, France, and Germany, 1870-1919. Charlottesville: University of Virginia Press.

O’Connor, Julia S., Ann Shola Orloff, and Sheila Shaver (1999) States, Markets, Families:

Gender, Liberalism, and Social Policy in Australia, Canada, Great Britain, and the United States. Cambridge, UK: Cambridge University Press.

Pelham, Laura Dainty (1909) “The Chicago city gardens association.” The Survey: Social, Charitable, Civic 22: 423-25.

Pingree, H.S. (1895) "Food for the poor." Chicago Daily Tribune, April 1

Piven, Frances Fox, and Richard A. Cloward (1977) Poor People's Movements: Why They Succeed, How they Fail. New York: Vintage Books.

Posner, Richard A. (2014) The Economic Analysis of Law, 9th ed. New York: Aspen. 
President's Organization on Unemployment Relief (1931) Press Release, October 29; reproduced in Monthly Labor Review 33: 77-78.

Price, C.W. (1907) Outline of talk on "Opportunity for recreation and social life" at Chicago Institute of Social Science, April 15. Wisconsin Historical Society, McCormickInternational Harvester collection.

Reider, Edith S. (1915) “With our Harvester gardeners.” Harvester World 6 (3): 23.

Salamon, Lester M. (1995) Partners in Public Service: Government-Nonprofit Relations in the Modern Welfare State. Baltimore: Johns Hopkins University Press.

Sanitary District of Chicago (1906) Proceedings of the Board of Trustees, March 14.

Satter, Beryl (2009) Family Properties: Race, Real Estate, and the Exploitation of Black Urban America. New York: Metropolitan.

Sherraden, Michael (1991) Assets and the Poor: A New American Welfare Policy. Armonk, NY: M. E. Sharpe.

Singer, Joseph (2000) "Property and social relations: From title to entitlement." In Charles Geisler and Gail Daneker (eds.), Property and Values: Alternatives to Public and Private Ownership. Washington, D.C.: Island Press: 3-19.

Singer, Joseph (2001) The Edges of the Field: Lessons on the Obligations of Ownership. Boston: Beacon Press.

Small, Mario Luis (2006) "Neighborhood institutions as resource brokers: Childcare centers, interorganizational ties, and resource access among the poor.” Social Problems 53 (2): 274-292.

Small, Mario Luis (2007) "Is there such a thing as 'the ghetto'?” City 11 (3): 413-421.

Smith, Dorothy E. (2005) Institutional Ethnography: A Sociology for People. Lanham, MD: AltaMira Press. 
Smith, Henry E. (2012) "Property as the law of things." Harvard Law Review 125(7): 16911726.

Smith, Steven, and Michael Lipsky (1995) Nonprofits for Hire: The Welfare State in the Age of Contracting. Cambridge, MA: Harvard University Press.

Sunstein, Cass R. (1996) “Social norms and social roles.” Columbia Law Review 96 (4): 903 968.

Thomas, William I., and Florian Znaniecki (1920) The Polish Peasant in Europe and America, Volume V: Organization and Disorganization in America. Boston: Richard D. Badger. United States Department of Commerce (1932) "Subsistence Gardens."

Urban Farm Pathways Project (2015) “Englewood community farms prospectus and business plan.”www.foodlandopportunity.org/downloads/Englewood_Prospectus_BusinessPlan.pdf (accessed July 6, 2018).

Voicu, Ioan, and Vicki Been (2008) "The effect of community gardens on neighboring property values." Real Estate Economics 36 (2): 241-283.

Walley, Christine J. (2013) Exit Zero: Family and Class in Postindustrial Chicago. Chicago: University of Chicago Press.

Weber, Max (2001 [1930]) The Protestant Ethic and the Spirit of Capitalism. London: Routledge.

Weir, Margaret, Ann Shola Orloff, and Theda Skocpol (1988) “Understanding American social politics." In Weir, Margaret, Ann Shola Orloff, and Theda Skocpol (eds.) The Politics of Social Policy in the United States. Princeton: Princeton University Press: 3-27.

West Chicago Park Commissioners (1920) A Greater West Park System: After the Plans of Jens Jensen. Chicago: West Park Commission. 
White, Monica M. (2011) "Sisters of the Soil: Urban gardening as resistance in Detroit." Race/Ethnicity: Multidisciplinary Global Contexts 5 (1): 13-28.

Williams, Raymond (1973) The Country and the City. New York: Oxford University Press.

Williamson, Samuel H. (2018) "Seven ways to compute the relative value of a US dollar amount, 1774 to present." www.measuringworth.com/calculators/uscompare (accessed July 3).

Winstanley, Gerrard (1649) The True Levellers Standard Advanced: Or, The State of Community Opened, and Presented to the Sons of Men.

Wolford, Wendy (2007) "Land reform in the time of neoliberalism: A many-splendored thing." Antipode 39 (3): 550-70.

Young, Arthur (1801) An Inquiry into the Propriety of Applying Wastes to the Better Maintenance and Support of the Poor. Angel Hill, UK: J. Rackham. 
TABLE 1. Four Modes of Welfare Provision

Beneficiary's Claim to Resource

\begin{tabular}{|c|c|c|c|}
\hline & & Owned by Beneficiary & Used by Beneficiary \\
\hline 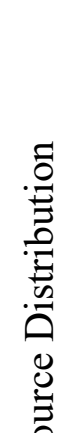 & $\begin{array}{l}\text { Tax and } \\
\text { Transfer }\end{array}$ & $\begin{array}{l}\text { Income-Based Welfare: } \\
\text { income supports or in-kind } \\
\text { transfer, e.g. AFDC, SNAP, } \\
\text { school meals. } \\
\text { Asset-Based Welfare: } \\
\text { ownership subsidized by tax } \\
\text { revenue, e.g. individual } \\
\text { development accounts. }\end{array}$ & $\begin{array}{l}\text { Service-Based Welfare: } \\
\text { services subsidized by tax } \\
\text { revenue, e.g. childcare, job } \\
\text { training, counseling by } \\
\text { community-based } \\
\text { organizations. }\end{array}$ \\
\hline $\begin{array}{l}+1 \\
0 \\
0 \\
0 \\
0\end{array}$ & $\begin{array}{l}\text { Adjusting } \\
\text { Property } \\
\text { Relations }\end{array}$ & $\begin{array}{l}\text { Asset-Based Welfare: } \\
\text { reallocation of ownership rights, } \\
\text { e.g. land reform, formalization of } \\
\text { squatters' rights. }\end{array}$ & $\begin{array}{l}\text { Use-Based Welfare: } \\
\text { reallocation of rights to use and } \\
\text { benefit from a resource, e.g. } \\
\text { use of vacant land for food } \\
\text { production; public library } \\
\text { makerspace; internet.org. }\end{array}$ \\
\hline
\end{tabular}

Note: Typology by the author. Asset-based welfare may involve redistribution via either tax-andtransfer subsidies (such as matching funds for individual development accounts), or adjustments to property relations (such as land reform). 